\title{
WACANA SOLIDARITAS DAN KEMAJEMUKAN ISLAM INDONESIA DI TENGAH PANDEMI COVID-19
}

\author{
Luqman Al Hakim \\ IAIN Jember \\ luqmanibnusuud@gmail.com \\ Muhammad Faiz \\ IAIN Jember \\ gen_cang@yahoo.com
}

\section{Abstrak}

Pandemi Covid-19 telak melumpuhkan banyak sisi kehidupan manusia. Dalam situasi ini umat Islam Indonesia turut diuji antara lain dalam aspek solidaritas dan kemajemukannya. Sebagai konsekuensinya terdapat dua pilihan bagi umat Islam Indonesia untuk menghadapi problem global ini, antara bersatu padu atau bercerai berai. Kemajemukan dan solidaritas sangat dibutuhkan bangsa Indonesia mengingat banyaknya elemen dalam tubuh umat Islam di Indonesia seperti beragamnya ormas. Di antara yang paling besar seperti Majelis Ulama Indonesia (MUI), Nahdlatul Ulama (NU) dan Muhammadiyah. Peran pemerintah dan ulama sangat dibutuhkan dalam mengatasi Covid-19. Penelitian ini bertujuan untuk melihat bagaimana perkembangan solidaritas dan kemajemukan Islam di tengah pandemi Covid-19 serta memetakan sejauh mana dampak solidaritas dan kemajemukan yang telah dihadirkan oleh umat Islam Indonesia. Metode penelitian yang digunakan ialah metode penelitian kualitatif, berbasis pengamatan sosial. Penelitian ini menegaskan bahwa wacana solidaritas Islam Indonesia semakin meningkat di masa pandemi yang dibuktikan dengan hadirnya bantuan sosial dan kegiatan kemanusiaan lainnya secara sukarelawan yang dilakukan umat Islam, utamanya dari ormas-ormas besar Islam di Indonesia. Meski tantangannya di sisi yang lain terdapat pula segolongan umat Islam yang mengendorkan solidaritas dan kemajemukan di masa pandemi Covid-19. Karenanya penting bagi umat Islam Indonesia untuk saling mendukung dan memberikan aksi nyata dalam menjunjung konsep solidaritas dan kemajemukan demi kemajuan bangsa bersama.

Kata Kunci: Covid-19, Solidaritas, Kemajemukan, Umat Islam Indonesia. 


\section{Abstract}

Covid 19 pandemic has demolished human activities, in period Covid 19 Indonesian Moslems being testing to inside solidarity and plurality. Because that has two choice to Indonesian Moslems united and separated. Plurality and solidarity very consucting remember for many Indonesian elemen Islam an example; MUI, NU, Muhammadiyah, etc. The role of government and preacher is big sake to loose Covid 19 misery. This research aim to looks how is development Moslems solidarity and plurality in the middle Covid 19, with maping to what extent impact solidarity and plurality is presenting from Indonesian Moslems. The research method used is kualitatif, have as base Social observation, result of this research Islamic concep solidarity and voluntary did Moeslems activities from the big Indonesian Islamic organizations with from any Islamic insantion. But in other that have present group Islam be delibelate solidarity and plurality in the time Covid 19. Importantly to Indonesia Moeslems for mutual supporting and giving real actions in support concep solidarity and plurality sake together benefit.

Keywords: Covid 19, solidarity and plurality, Indonesian Moslems

\section{Pendahuluan}

Indonesia merupakan negara yang dihuni oleh mayoritas umat Islam. Masyarakat (manusia)-nya dalam berbagai bentuk kesatuan seperti komunitas, umat, maupun sekadar kelembagaan atau organisasi dapat dinyatakan dalam kategori yang dinamis. Oleh sebab itu, dibutuhkan solidaritas di tengah kemajemukan yang ada.

Umat Islam Indonesia sangat majemuk dengan aneka warna ideologi (pandangan agama) yang ada. Karena itu dalam merangkul kemajemukan dan menumbuhkan solidaritas dibutuhkan kepemimpinan yang baik yang turut memperhitungkan dinamika tersebut. Selain dibutuhkan kepemimpinan yang baik, aspek akomodasi yang berorientasi positif terhadap hadirnya perubahan yang bersifat kemestian turut menjadi keniscayaan. Apalagi di era Covid-19 solidaritas sangat dibutuhkan demi menciptakan kehidupan yang baik di tengah nuansa kemajemukan yang telah ada. ${ }^{1}$

Al-Qur'an sendiri mengakui bahwa fenomena pada alam semesta terus berubah, termasuk masyarakat (manusia). hanya yang tidak pernah berubah adalah Al-Khaliq sendiri (QS. ar-Rahman: 27) dan nilai-nilai ilahiah atau tauhid tentunya. Begitu juga

\footnotetext{
${ }^{1}$ Nurcholish Madjid, Kaki Langit Peradaban Islam (Jakarta: Dian Rakyat, 2009), 193.
} 
dengan sunnatullah terus berlaku sepanjang masa tanpa mengalami perubahan (QS. Fathir: 43).

Berbicara perubahan sosial (social change) pada umumnya akan bertemu dengan tiga macam pendekatan, yaitu; pendekatan konservatif, radikal atau revolusioner, dan reformis. Dalam pandangan Islam, pendekatan konservatif tidak diunggulkan. Konservatisme umumnya didukung kaum formalis dan pembela-buta tradisi serta yang tergolong dalam kaum ulama obskurantis.

Konservatisme mengarah pada pelestarian adat istiadat yang berwatak irrasional. Pendekatan radikal-revolusioner mengarah pada pencerahan tradisi sampai ke akarakarnya dan menganggap pelestarian tradisi sebagai stagnasi sosial. Adapun pendekatan reformsime sebagai jalan tengah antara konservatisme dan radikalisme. ${ }^{2}$

Covid-19 memaksa keadaan sosial untuk berubah, sehingga banyak umat Islam Indonesia yang terpaksa merubah pola sosial kehidupannya. Banyak dari mereka kehilangan tempat berpijak untuk menyambung hidup dan akses kemudahan sosial. Dengan demikian dimulailah tantangan untuk menguji sejauhmana solidaritas dan kepekaan yang ada, oleh itu tujuan penelitian ini adalah untuk melihat bagaimana perkembangan solidaritas dan kemajemukan Islam di tengah gempuran pandemik Covid-19.

Selain itu juga memetakan sejauh mana dampak solidaritas dan kemajemukan yang telah dihadirkan oleh umat Islam Indonesia. Sebagai harapan dengan hadirnya penelitian ini dapat menjadi tolok ukur dalam gambaran solidaritas sesama umat Islam khususnya bagi mereka yang membutuhkan uluran tangan tanpa mengenal latarbelakang ormas dan aliran yang bekerja secara sukarela menyalurkan bantuan.

Sebelumnya mengenai konsep agama dan solidaritas yang diteliti oleh Kamiruddin menjelaskan keumuman proses dan bentuk solidaritas dengan bercermin pada pandangan Emil Durkheim tanpa menjelaskan konsep real yang hadir di masyarakat. Ade Dedi Rohayana dalam Islam dan Kemajemukan, menjelaskan kemajemukan di era reformasi menjadi beban pada modal bangsa Indonesia, serta belum menjelaskan bagaimana upaya dari internal Islam sendiri untuk memperkokoh

\footnotetext{
${ }^{2}$ M Amien Rais, Cakrawala Islam Antara Cita dan Fakta (Bandung: Mizan, 1991), 136.
} 
eksistensi persaudaraan sesama Islam. Sehingga hadirnya penelitian ini salah satunya untuk meneropong bagaimana upaya elemen umat Islam di lapangan khususnya selama era pandemi Covid-19 berlangsung.

Pembahasan penelitian ini secara garis besar menyangkut tiga pembahasan; Pertama, solidaritas sebagai wadah keumatan Islam. Kajian ini mendasarkan ikatan ukhuwah sesama umat Islam, mengelaborasi peran-peran organisasi dan institusi Islam dalam mengokohkan solidaritas dan kemajemukan di tengah pandemi Covid-19. Kedua, kemajemukan dan pembangunan sumberdaya manusia (SDM) kalangan Islam. kajian ini mendasarkan penelitian bagaimana kelanjutan peran organisasi dan institusiinstitusi Islam dalam menjembatani pembangunan SDM berkelanjutan di masa Covid19. Ketiga, membahas stereotype yang menggejala di tengah kemajemukan masyarakat Indonesia. Diharapkan dengan hadirnya penelitian ini dapat meningkatkan semangat solidaritas dan melunturkan stereotype antara sesama penganut Islam demi kemajuan bangsa dan agama tentunya.

\section{Solidaritas Sebagai Wadah Keumatan Islam}

Secara historis agama pada hakikatnya telah memainkan peran besar dalam menstimulasi aksi-aksi sosial keagamaan untuk aksi kemanusiaan. Selain itu agama juga turut menjadi kritik atas keadaan sosial dan menjadi simbol perlawanan dari manusia atas takdir yang menimpa. karenanya aksi sosial dapat direfleksikan sebagai model perubahan secara kultural dan struktural. Sehingga menghadirkan nuansa yang dinamis dengan meningkatnya kontrol atas masyarakat.

Dalam praktik kehidupan sosial keagamaan di Indonesia terdapat berbagai elemen Islam yang turut berperan dan berpengaruh dalam menjalankan aktivitas keagamaan secara massif dan menonjol. Dalam hal ini seperti Nahdhatul Ulama (NU), Majelis Ulama Indonesia (MUI), Muhammadiyah, serta ormas-ormas Islam yang lain turut berpengaruh kepada masyarakat dalam jumlah yang besar atau signifikan. Dalam pendekatan sosiologis, "mainstream” atau keagamaan bukan konsep mutlak dan abadi, mainstream adalah paham yang didukung penguasa dan dianut oleh mayoritas. ${ }^{3}$

\footnotetext{
${ }^{3}$ Zuly Qodir, Radikalisme Agama di Indonesia (Yogyakarta: Pustaka Pelajar, 2014), 4.
} 
MUI mengeluarkan instruksi yang ketat terkait permasalahan pandemi Covid19, dalam kaitan tindakan yang menimbulkan kepanikan atau menyebabkan kerugian publik seperti memborong dan menimbun bahan kebutuhan pokok, menimbun masker, serta menyebarkan hoax terkait Covid-19 ditegaskan sebagai perbuatan yang haram hukumnya dilakukan. Instruksi tersebut tepat sebab dengan tidak menimbun dan aksi panic buying menyebabkan masyarakat lebih tercukupi kebutuhan sandang mereka, dengan demikian terciptalah solidaritas bagi sesama. ${ }^{4}$

Peran Lazis NU dan lazis Muhammadiyah (Lazis MU) sangat nampak dalam penyaluran dana Covid-19 dalam meringankan korban pandemi Covid-19. Seperti pada bulan ramadhan $1441 \mathrm{H}$ salah satu acara televisi swasta menggalang dana untuk guru ngaji, mejelis taklim dan pondok pesantren terdampak virus corona, dalam acara tersebut terkumpul Rp 881.148.036 yang akan didonasikan kepada 3.000 penerima melalui LAZISNU.

Selain itu LAZISNU juga menyelurkan sebanyak 1.000.000 sembako bagi warga yang terdampak dan sudah berjalan di masa awal pandemi. ${ }^{5}$ Dalam kerjanya LAZISNU juga menggandeng Tokopedia dalam meningkatkan pelayanan pada masyarakat pada 21 Juli 2020 dengan mendistribusikan bantuan yang disalurkan dalam bentuk 312 paket makanan sehat dan siap santap kepada masyarakat yang membutuhkan di seluruh wilayah DKI Jakarta. ${ }^{6}$

Muhammadiyah dengan lembaga LAZISMU dan MCCC (Mubammadiyah Command Covid Center) menginformasikan berbagai hal tentang Covid-19, seperti pola hidup sehat, tuntunan ibadah, termasuk survei yang dilakukan terhadap masyarakat. MCCC juga menjalin kerja sama baik dari nasional dan internasional, seperti menyalurkan 500.000 paket di seluruh Indonesia dengan jumlah dana yang

\footnotetext{
${ }^{4}$ Muhammad Agus Mushodiq, dan Ali Imron, "Peran Majelis Ulama Indonesia dalam Mitigasi Pandemi Covid-19 Tinjauan Tindakan Sosial dan Dominasi Kekuatan Max Weber," Jurnal Salam: Sosial E Budaya Syar'i 7, No. 5 (2020): 463.

${ }^{5}$ Tim JPNN, "NU Care-LAZISNU Salurkan Bantuan kepada Masyarakat Terdampak Covid-19," https://www.google.com/amp/s/m.jpnn.com/amp/news/nu-care-lazisnu-salukan-bantuan-kepadamasyarakat-terdampak-covid-19 (diakses pada 20 Desember 2020).

${ }^{6}$ Abdul Rochim, "NU-Care LAZISNU Salurkan Bantuan untuk Masyarakat Terdampak Covid-19," https://nasional.sindonews.com/read/108844/15/nu-care-lazisnu-salurkan-bantuan-untuk-masyarakatterdampak-covid-19-1595347652 (diakses pada 20 Desember 2020).
} 
dikeluarkan baik sendiri maupun bantuan internasional sebanyak 450 miliar rupiah, diperkirakan total penerima manfaat mencapai 28 juta jiwa. ${ }^{7}$

Selain NU dan Muhammadiyah, Lembaga e-Learning Islam Halaqah Silsilah Ilmiyah turut menyumbang 150 juta kepada Ikatan Dokter Indonesia (IDI) yang digunakan untuk penanggulangan Covid-19 selain uang 150 juta. HSI juga memberikan donasi berupa alat pelindung diri (APD), hand sanitizer, masker beda, masker N95, sarung tangan, alkohol 70\% dan suplemen gizi bagi tim medis kepada sejumlah rumah sakit di Jakarta, Surakarta, Banten, Yogyakarta, dan Semarang serta masih banyak lagi elemen-elemen Islam yang mendukung kuatnya solidaritas dan kebersamaan di tengah Covid-19. ${ }^{8}$

Dengan demikian, dengan mewabahnya Covid-19 bagi umat Islam ternyata semakin membuka kesadaran kolektif akan pentingnya solidaritas dan mengelola kemajemukan yang terbukti dengan banyaknya distribusi bantuan baik material maupun non material yang diberikan kepada korban Covid-19 di penjuru Indonesia.

\section{Kemajemukan dan Pembangunan SDM Umat Islam}

Perkembangan zaman menggiring manusia pada era kompetitif, sehingga inovasi dalam menciptakan ide-ide dan karya baru menjadi tuntutan utama salah satunya diterapkan dalam mengemas pesan persuasif dan kontekstual, kemudian pesan tersebut diimplementasikan pada berbagai kegiatan maupun media tertentu. Indonesia adalah negara yang kaya akan budaya, tentunya diperlukan SDM yang mumpuni dari segala aspek untuk merawat kemajemukan tersebut, baik dalam aspek ekonomi, pendidikan, dan penguatan dalam sektor keagamaan. Era Covid 19 memaksa untuk lebih berjuang menciptakan SDM yang tangguh dan unggul. Dalam paradigma interpretatif Martin dan Nakayama (2010) menegaskan bahwa ada rethorical approach sebagai salah satu cara untuk menafsirkan sebuah objek penelitian yang dimaksud, dapat berupa lisan atau

\footnotetext{
7 Tim LAZISMU, "Program dan Pencapaian 9 Bulan Muhammadiyah Covid-19 Command Center", https://lazismu.org/blog/lazismu-pusat-45/post/program-dan-pencapaian-9-bulan-muhammadiyahcovid-19-command-center-2162 (diakses pada 20 Desember 2020).

8 Yudistira Imandiar, "Lembaga e-Learning Agama Islam Ini Sumbang Rp 150 Juta ke IDI", https://news.detik.com/berita/d-4971631/lembaga-e-learning-agama-islam-ini-sumbang-rp-150-juta-keidi (Diakses pada 20 Desember 2020).
} 
tulisan sesuai konteks yang ada dalam masyarakat. Begitu juga dengan kemajemukan dan pembangunan SDM Islam dibutuhkan aksi dan tindakan lanjutan penting diketahui bahwa jika SDM berkurang maka akan berdampak besar pada keberlangsungan suatu bangsa. ${ }^{9}$

Salahsatu cara untuk meningkatkan SDM dengan mengedukasi pentingnya $3 \mathrm{M}$; mencuci tangan, mengenakan masker, dan menjaga jarak. Edukasi seperti demikian penting sebab Covid-19 dapat menyerang siapa saja oleh sebab itu 3 M merupakan usaha untuk mengurangi virus tersebut, pemerintah, organisasi-organisasi Islam, dan elemen-elemen lainnya telah berusaha menyerukan kepada masyarakat umum sehingga diharapkan dapat mematuhi protokol kesehatan. MUI juga telah menerbitkan pelaksanaan ibadah di masa pandemik Covid-19. Beragama Islam, tidak dapat dilakukan setengah-setengah. Sebab berislam juga melibatkan jiwa dan raga, orang tidak hanya mengikuti satu ajarannya dan meninggalkan ajaran yang lainnya yang tidak disukai, seseorang tidak hanya dapat menyukai aspek spiritual Islam saja akan tetapi juga mengikuti amalan ritualnya.

Beragama di tengah pandemik sangat dibutuhkan, banyak orang diluarsana yang bunuh diri dan stres sebab pendemik yang tidak kunjung usai, akan tetapi bagi orang yang beriman mereka tidak akan bunuh diri ataupun stres sebab mereka yakin bahwa segala yang ada merupakan ujian atau cobaan sehingga mereka berserah diri sebab segenap usaha telah dilakukan. Islam sendiri di masa pandemik juga menyuruh bertawakal disamping berusaha dengan jalan jasmaniah. Sebagaimana yang dikatakan Imam al-Ghazali, tawakal berarti penyerahan diri kepada Tuhan yang maha pelindung sebab sesuatu tidak keluar dari ilmu dan kekuasaan-Nya, sedangkan selain Allah tidak dapat membahayakan dan memberikan manfaat, seorang Islam wajib beriman dalam tataran keilmuwan maupun praktis sehingga ajaran agama dapat maximal tersalurkan.

Pada tataran sosial sesama manusia saling dianjurkan untuk bahu membahu terkhusus di masa Covid-19, bahu membahu tidak hanya bersifat material akan tetapi juga dapat menjadi sukarelawan berguna dengan tenaga yang dimiliki, terbukti dengan

\footnotetext{
${ }^{9}$ Rustono Farady Marta dan Jean Sierjames Rieuwpassa,"Identifikasi Nilai Kemajemukan Indonesia Sebagai Identitas Bangsa dalam Iklan Mixagrip Versi Keragaman Budaya,"Jurnal Kajian Komunikasi 6, No. 1 (Juni 2018), 41.
} 
banyaknya sukarelawan yang hadir untuk menolong sesama di masa pandemik. ${ }^{10}$ Peran dan pendidik penting dalam mengembangkan SDM, sebab seorang pendidik harus memahami filosofi mendidik, paham akan karakter murid. Pendidikan karakter bukan hanya pendidikan yang mengedepankan pengetahuan rasional, akan tetapi pendidikan yang berlandaskan hati nurani, yang disentuh bukan hanya kepekaan rasio saja, namun juga kepekaan hati. Metode pembelajaran daring di masa pandemik Covid-19 menyulitkan tatapmuka antara pendidik dan murid, mesipun demikian pada titik ini peran pendidik semakin dipertajam sehingga harus lebih inovatif dalam menyampaikan materi, agar murid tidak bosan dan antusias.

Dengan penanaman moralitas yang baik diharapkan akan menciptakan generasi yang berkarakter dan peduli kepada sesama. Terdapat tiga landasan pendidikan berkarakter. Pertama, prinsip keagamaan ialah prinsip ketauhidan yang berbasis pada pengesaan Allah dan persaksian Muhammad sebagai Rasul. Konsep tersebut ialah perwujudan kalaimat tauhid, "La ilaha Illallah, Muhammadur Rasulullah." Konsep tersebut dapat diimplementasikan dalam tataran ibadah dan akhlak yang merupakan prinsip dasar dalam ajaran Islam. Kedua prinsip kebangsaan, penegakan terhadap empat pilar bangsa, Pancasila, UUD 1945, NKRI, dan Kebhinekaan. Pilar kebangsaan penting, sebab bagaimanapun bangsa ini harus eksis ditengah pergaulan bangsa-bangsa dan setiap tantangan zaman. Ketiga, prinsip implementatif dalam prinsip ini maka semua konsep pendidikan Lillah Billab yang dicerminkan dalam kejujuran, keterbukaan dan akuntabilitas yang dapat dinilai dan diuji. Hanya saja pendidikan karakter tersebut tidak cukup dengan kehebatan intelektual akan tetapi perlu didukung daya implementasi dan tindakan. ${ }^{11}$

Pembangunan dalam aspek politik juga tidak ketinggalan penting, dengan menghadirkan perwakilan-perwakilan yang baik dan strategis di tengah Covid 19, meyuarakan transparansi dan akuntabilitas. Masyarakat diajak untuk mengetahui politik agar tidak kecolongan hak mereka di tengah pandemik Covid 19, setidaknya terdapat elit-elit politisi atau partai yang membantu melawan Covid 19 sebagai balas

\footnotetext{
${ }^{10}$ Hamid Fahmy Zarkasyi, Minhaj Berislam dari Ritual hingga Intelektual (Jakarta: INSIST, 2020), 22.

${ }^{11}$ Nur Syam, Menjaga Harmoni Menuai Damai Islam, Pendidikan, dan Kebangsaan (Jakarta: Kencana, 2018), 73.
} 
budi atas suara rakyat yang dilimpahkan kepada mereka. Terdapat beberapa contoh baik yang dilakukan partai dan elit politik seperti yang terjadi di Gowa dengan menyalurkan APD dan hand sanitizer di masjid-masjid, selain itu peran PKS dalam membagikan sabun cuci tangan dan antiseptic di setiap masjid di Tompobulu, pandemik Covid 19 menghadirkan banyak kekhawatiran ekonomi masyarakat. Banyak yang kehilangan pekerjaan dan berkurangnya pendapatan rumah tangga. Pandemik mulai membuka mata masyarakat, dengan mengesampingkan motif politik, sesungguhnya dititik ini terdapat peluang untuk mencari simpati publik dengan aksi membantu pemerintah dan ormas Islam yang dilakukan oleh elit-elit partai dengan bantuanbantuan sederhana. ${ }^{12}$

\section{Stereotype di tengah Kemajemukan}

Ruang publik di tengah pandemik Covid-19 mengalami dinamika yang signifikan bagaimana tidak ruang publik yang menjadi ruang bersama sebagai ajang berbagi opini menjadi serba terbatas, menjauh dari Covid-19 berrati menjauh dari kerumunan masyarakat. Ruang publik yang hadir disekitar dapat ditemukan di masjid, taman, warung kopi, maupun cafe, hadirnya ruang publik penting demi menyalurkan opini dan musyawarah bersama,komunikasi sebagai proses pertukaran pesan yang dilakukan oleh satu individu kepada individu atau kelompok yang lain. Komunikasi menurut prespektif Islam dapat dilakukan dengan siapapun untuk memberi kemanfaatan di balik pesan yang akan disampaikan. Komunikasi memiliki peran penting untuk mengontrol sosial dalam kehidupan bermasyarakat.

Latar belakang yang berbeda menghadirkan perbedaan budaya, dan kepercayaan, akan tetapi di tengah pandemik muncul budaya baru yakni stereotype antara individu, saling mencurigai mengenai penularan Covid 19. Bahkan dampaknyajuga besar bisa saja dikucilkan dari pergaulan sehingga memaksa individu tersebut untuk mencari alternatif demi kesehatan. Covid 19 memicu meningkatnya budaya individualisme dan secara pelan-pelan menghapus budaya kebersamaan. Selama

${ }^{12}$ Ramlah, "Kontribusi Partai Politik di Tengah Pandemik Covid-19 di Kabupaten Gowa," Jurnal Vox Populi 3, No. 1 (Juni 2020): 58. 
wabah Covid-19 terjadi pergeseran dalam ruang publik dalam dimensi virtual, melirik dengan pola perkembangan ruang publik yang baru menurut Habermas jelas bahwa komunikasi antarbudaya hadir secara tidak langsung, yang umumnya dalam satu ruang publik dihadiri oleh banyak orang yang berasal dari golongan, lapisan, dan kelompok yang berbeda. Namun saat ini melebur menjadi satu ruang publik secara (virtual) melekukan iteraksi dan meneyelsaikan persoalan yang menyangkut kemaslahatan bersama. $^{13}$

Perasangka saling mencurigai yang muncul tidak dapat untuk dihindarkan, perubahan yang demikian tidak dapat direncanakan dan tidak dikehendaki oleh masyarakat. Akan tetapi, demi menjaga kesehatan suka tidak suka harus dijalankan, Covid-19 ialah bencana yang tidak dapat diperkirakan kapan usainya dan sejauh mana jangkauannya dalam sendi-sendi kehidupan manusia. Karena terjadi diluar perkiaraan, perubahan ini sering membawa kekacauan dan kendala dalam masyarakat. Oleh karenanya perubahan yang tidak dikehendaki sangat sulit ditebak akapan terjadi. Perubahan yang disebabkan Covid-19 dapat dikatakan berpengaruh besar (makro) sebab mengakibatkan perubahan dalam tatanan kemasyarakatan, hubungan kerja, sistem mata pencaharian terbukti dengan banyaknya PHK masal dan cuti yang tidak jelas kapan masuknya. Menurut Selo Soemardjan, perubahan sosial adalah perubahan yang terjadi pada lembaga-lembaga kemasyarakatan di dalam suatu mayarakat yang mempengaruhi sistem sosial- nya. ${ }^{14}$

Jelas bahwa Covid-19 turut berperan dalam perubahan lembaga-lambaga masyarakat banyak social change yang terjadi, bahka turut mempengaruhi bagaimana opini dan sikap yang diambil masyarakat dalam membaca realitas di lapangan. Memahami proses sosial yang dilakukan masyarakat di era pandemik virus Covid-19 perlu dilakukan pendekatan dalam kajian sosiologis, seperti intervensi sosial dengan melakukan pelayanan sosial masyarakat guna memahamkan bagaimana keadaan yang terjadi disamping itu aktivitas ini penting guna meminimalisir stereotype yang terjadi dalam tubuh masyarakat. Serta menyeimbangkan sosial dan berinteraksi secukupnya

\footnotetext{
${ }^{13}$ Andri Kurniawan, Nibrasatul Yumna, dan Erna Tantri, Esistensi Ruang Publik di tengah Covid19: Perspektif Islam dan Komunikasi Multikultural," Jurnal Komunike 12, No. 1 (Juni 2020): 36.

${ }^{14}$ Imam Bonjol Jauhari, Sosiologi Untuk Perguruan Tinggi (Jember: STAIN Jember Press, 2014), 43.
} 
tanpa harus melakukan hal-hal yang berlebihan sehingga mengakibatkan ketimpangan dalam proses interaksi sosial. Akan tetapi terdapat fenomena yang unik di pedesaan pada umumnya, di mana mereka sudah mulai melakukan kegiatan pada umumnya tanpa ada rasa khawatir akan Covid-19, kebanyakan tidak memakai dan tidak menjaga jarak. Keadaan ini disebabkan dengan melebarnya stratifikasi sosial yang ada, dengan gejolak ekonomi, kehilangan sumber penghasilan dan melebarnya kemiskinan. ${ }^{15}$

Kemajemukan yang ada di Indonesia ibarat pisau bermata dua satu aspek membawa berkah, disisi yang lain membawa bencana. Covid-19 telah menyebar di seluruh Indonesia, otomatis seluruh mobilitas di batasi dan kebebasan dikurangi, selain itu meskipun sudah mengantongi hasil rapid test atau $S$ wab masih ada segolongan yang sering menstigma negatif dan lebih susahnya lagi dikucilkan sehingga menghadirkan dampak psikologis yang besar. Apalagi bagi mereka yang sudah positif terkena Covid 19 pastinya akan lebih hebat bahkan keluarga mereka tidak luput dari sasaran diskriminasi, oleh sebab itu harus dilakukan anulir dengan literasi kesehatan yang optimal dari berbagai pihak . dukungan segenap pihak untuk mengedukasi pada masyarakat demi meminimalisir stigma negatif termasuk bagi penderita Covid-19, serta memperhatikan pola hidup sehat dan mengkonsumsi vitamin $\mathrm{C}$ dan $\mathrm{E}$, dan mengikuti anjuran pemerintah dan Kemenkes. ${ }^{16}$

Dengan demikian, hadirnya Covid-19 telah membuka kepedulian segenap elemelemen Islam di Indonesia, wacana solidaritas Islam Indonesia semakin meningkat di masa pandemik dibuktikan dengan hadirnya bantuan sosial, dan kegiatan sukarelawan yang dilakukan umat Islam baik dari ormas-ormas Islam besar Indonesia maupun dari instansi Islam yang lain. Akan tetapi disisi yang lain terdapat pula segolongan umat Islam yang mengendorkan solidaritas dan kemajemukan di masa pandemik Covid-19. Penting bagi umat Islam Indonesia untuk saling mensupport dan memberikan aksi nyata dalam mendukung konsep solidaritas dan kemajemukan demi kemanfaatan bersama.

${ }^{15}$ Siti Rahma Harahap, "Proses Interaksi Sosial Di Tengah Pandemi Virus Coid 19", (Jurnal AlHikmah: Media Dakwah, Komunikasi, Sosial dan Budaya, Volume. 11, No. 1, Juni 2020), 50.

${ }^{16}$ Ramly Abudi, Yasir Mokodompis, dan Allika Nurfadias Magulili, "Stigma Terhadap Orang Positif Covid-19", (Jurnal Jambura, Volume. 2, No. 2, Juli 2020), 82. 
Ditinjau dari teori solidaritas Emil Durkheim yang terbagi menjadi dua, solidaritas organik dan mekanik. Solidaritas mekanik didukung oleh persamaan individu. Umumnya solidaritas mekanik terdapat dalam sistem masyarakat yang sangat sederhana, bersahaja, primitip bahkan disebut tidak identik antara satu dengan yang lain serta sistem pembagian kerjanya belum diklasifikasi. ${ }^{17}$ Berbeda dengan solidaritas organis, dalam tatanan solidaritas organis sistem pembagian kerja sudah diklasifikasikan dan bersifat terorganisir dan pola masyarakatnya sudah heterogen. Begitu pula dengan penangan Covid yang dilakukan elemen-elemen Islam sudah terorganisir dan tersistematis sehingga lebih maksimal dalam penanganannya. Dari penelitian terdahulu sebagaimana yang terdapat di pendahuluan.

\section{Simpulan}

Secara garis besar hadirnya Covid-19 telah merubah pola komunikasi dan interaksi yang ada pada masyarakat, menimbulkan kesusahan dalam segenap aspek kehidupan, dengan maraknya PHK, meningkatnya kemiskinan, dan semakin sulitnya aspek mobilisasi individu. Covid-19 membuka mata kita untuk semakin peka terhadap sesama terbukti dengan maraknya aksi donasi yang dilakukan NU, Muhammadiyah, dan elemen-elemen Islam yang lain, serta meningkatnya aturan ibadah dan aturan kerumunan pada masa pandemi melalui Peraturan Pemerintah. Hadirnya Covid-19 juga turut meningkatkan perasaan stereotype di tengah masyarakat, di mana masyarakat takut akan momok Covid-19. Oleh sebab itu, dibutuhkan dukungan dan edukasi dari berbagai pihak demi kebaikan bersama.

Peran pemerintah dan Ulama besar disini salah satunya dengan penguatan aspek rohani, sebab suara dan kebijakan mereka dapat mengubah situasi dan kondisi yang ada. Dengan banyaknya latar budaya dan pendidikan masyarakat diedukasi pentingnya menjaga protokoler kesehatan, dengan menanamkan teladan yang baik sebab Covid-19 tidak pandang bulu dan tidak bisa diprediksi kapan menyerang lingkungan kita. Jagalah diri dan keluarga dari Covid-19.

\footnotetext{
${ }^{17}$ Kamiruddin, "Agama dan Solidaritas Sosial: Pandangan Islam terhadap Pemikiran Sosiologi Emil Durkheim," Jurnal al-Fikra 5, No. 1 (Januari-Juni 2006): 73.
} 


\section{Daftar Pustaka}

Abudi, Ramly, Yasir Mokodompis, dan Allika Nurfadias Magulili. "Stigma terhadap Orang Positif Covid-19.” Jurnal Jambura 2, No. 2 (Juli 2020): 77-84.

Harahap, Siti Rahma. "Proses Interaksi Sosial di tengah Pandemi Covid-19.” Jurnal alHikmah: Media Dakwah, Komunikasi, Sosial, dan Budaya 11, No. 1 (Juni 2020): 45-53.

Imandiar, Yudistira. “ Lembaga e-Learning Agama Islam Ini Sumbang Rp 150 Juta ke IDI.”https://news.detik.com/berita/d-4971631/lembaga-e-learning-agama-islamini-sumbang-rp-150-juta-ke-idi (Diakses pada 20 Desember 2020).

Jauhari, Imam Bonjol. Sosiologi Untuk Perguruan Tinggi. Jember: STAIN Jember Press, 2014.

Tim JPNN. "NU Care-LAZISNU Salurkan Bantuan Kepada Masyarakat Terdampak Covid-19." https://www.google.com/amp/s/m.jpnn.com/amp/news/nu-carelazisnu-salukan-bantuan-kepada-masyarakat-terdampak-covid-19 (Diakses pada 20 Desember 2020).

Tim LAZISMU. "Program dan Pencapaian 9 Bulan Muhammadiyah Covid-19 Command Center." https://lazismu.org/blog/lazismu-pusat-45/post/programdan-pencapaian-9-bulan-muhammadiyah-covid-19-command-center-2162

(Diakses pada 20 Desember 2020).

Kamiruddin. "Agama dan Solidaritas Sosial: Pandangan Islam terhadap Pemikiran Sosiologi Emil Durkheim." Jurnal Al-Fikra 5, No. 1 (Januari-Juni 2006): 70-83.

Kurniawan, Andri, Nibrasatul Yumna, dan Erna Tantri. "Esistensi Ruang Publik di tengah Covid-19: Perspektif Islam dan Komunikasi Multikultural.” Jurnal Komunike 12, No. 1 (Juni 2020): 24-40.

Madjid, Nurcholish. Kaki Langit Peradaban Islam. Jakarta: Dian Rakyat, 2009.

Marta, Rustono Farady, dan Jean Sierjames Rieuwpassa. "Identifikasi Nilai Kemajemukan Indonesia Sebagai Identitas Bangsa dalam Iklan Mixagrip Versi Keragaman Budaya.” Jurnal Kajian Komunikasi 6, No. 1 (Juni 2018): 37-50.

Mushodiq, Muhammad Agus dan Ali Imron. "Peran Majelis Ulama Indonesia dalam Mitigasi Pandemi Covid-19: Tinjauan Tindakan Sosial dan Dominasi Kekuatan Max Weber.” Jurnal Salam: Sosial E Budaya Syar’i 7, No. 5 (2020): 455-472.

Qodir, Zuly. Radikalisme Agama di Indonesia. Yogyakarta: Pustaka Pelajar, 2014.

Rais, M Amien. Cakrawala Islam Antara Cita dan Fakta. Bandung: Mizan, 1991. 
Ramlah. "Kontribusi Partai Politik di tengah Pandemik Covid-19 di Kabupaten Gowa." Jurnal Vox Populi 3, No. 1 (Juni 2020): 53-59.

Rochim, Abdul. "NU-Care LAZISNU Salurkan Bantuan untuk Masyarakat Terdampak Covid-19.” https://nasional.sindonews.com/read/108844/15/nucare-lazisnu-salurkan-bantuan-untuk-masyarakat-terdampak-covid-191595347652 (Diakses pada 20 Desember 2020).

Syam, Nur. Menjaga Harmoni Menuai Damai Islam, Pendidikan, dan Kebangsaan. Jakarta: Kencana, 2018.

Zarkasyi, Hamid Fahmy. Minhaj Berislam dari Ritual bingga Intelektual. Jakarta: INSIST, 2020. 